\title{
Effect of Balanced Ration Supplementation on Body Weight Gain and Milk Yield in Different Breeds of Cattle
}

\author{
Krishna Murthy Atturi ${ }^{1}$, Ajay Singh ${ }^{2 *}$, Kalyana Chakravarthi Matha ${ }^{3}$, \\ Dhanalakshmi Guduru ${ }^{1}$ and Y.G. Prasad ${ }^{5}$
}

\author{
${ }^{\text {l} S H E \& C S ~ K r i s h i ~ V i g y a n ~ K e n d r a, ~ Y a g a n t i p a l l e, ~ K u r n o o l ~ D i s t, ~ A n d h r a ~ P r a d e s h, ~ I n d i a ~}$ \\ ${ }^{2}$ Animal Nutrition, College of Veterinary Sciences (Sri Venkateswara Veterinary University), \\ Proddatur - 516360, Andhra Pradesh, India \\ ${ }^{3}$ LFC, College of Veterinary Science, Proddatur, India \\ ${ }^{4}$ ATARI, Zone- $X$, Hyderabad, India
}

*Corresponding author

\begin{tabular}{|l|}
\hline Ke y w o r d s \\
Balanced ration \\
supplementation, \\
Body weight, \\
Milk yield
\end{tabular}

\section{A B S T R A C T}

Feeding management of dairy animals plays a major role on milk production in dairy animals. Balanced feeding with effective utilization of available feeds and fodder reduces the cost on dairy animal feeding. A field trial was conducted to assess the effect of balanced feeding on body weight gain and milk production in different breeds of cattle. A total of 30 milch cows consisting of Crossbred Jersey $(n=9)$, crossbred Holstein Friesian $(n=10$ and Ongole $(n=11)$ were selected for the study from three different villages in Banaganapallemandal of Andhra Pradesh. Initial data (T1) on body measurements, body weight, milk yield and Fat in milk was collected. Balanced ration was formulated using an android application "Ration Formulator" developed by Sri Venkateswara Veterinary University, Tirupati. The cows were fed with the recommended quantity of feed ingredients for 30 days. Final data (T2) was collected on the above parameters. The data revealed that among the three breeds, Ongole cows gain more body weight $(38.2 \mathrm{~kg})$ followed by crossbred jersey $(36.8 \mathrm{~kg})$ and crossbred HF $(29.11 \mathrm{~kg})$. Among the three breeds, highest improvement in 3.5\%FCM milk was recorded in Ongole (48.7\%) followed by Crossbred jersey (33.5\%) and crossbred HF (14.25\%). The experiment concluded that feeding balanced ration advanced tools improves body weight gain and milk production in dairy animals.

\section{Introduction}

Dairy cattle production in India is characterized by low productivity levels due to genetic and nutritional constraints. Dairy farming is an important livelihood option under rainfed agriculture. Feeding management of dairy animals has to be improved to get full potential production. The traditional system of dairy animal feeding is mostly depending on the agricultural waste/by products like straws, haulms along with 
limited grazing lands. Balanced feeding of dairy animals with effective utilization of available feed resources improves the production and reproduction efficiency of dairy animals with higher net returns. The average daily milk production data of $6.52 \mathrm{~kg}$ for crossbreds, $2.10 \mathrm{~kg}$ for indigenous cattle and $4.44 \mathrm{~kg}$ for buffaloes suggests that the productivity of these animals is far below their genetic potential. Imbalanced feeding leads to excess feeding of some nutrients whilst others remain deficient. This not only reduces milk production and increases costs per $\mathrm{kg}$ milk, but also affects various physiological functions including long term animal health, fertility and productivity. Since many smallholder farmers do not have the necessary skills and knowledge to prepare balanced rations, this can be achieved through providing ration balancing advisory services directly to the farmers. Keeping this in view, the following experiment was conducted with the following objectives.

To study the effect of balanced feeding on body weight gain in different cattle breeds

To study the effect of balanced feeding on production performance in different breeds of cattle.

To study the efficiency of android application developed by Sri Venkateswara Veterinary University, Tirupati for formulation of balanced rations.

\section{Materials and Methods}

\section{Selection of animals}

Farmers were selected based on their willingness for implementing the ration balancing programme. Thirty dairy animals of Crossbred Jersey (JX), Crossbred Holstein Friesian (HFX) and Ongole were selected in three villages viz. Meerapuram, Yagantipalle and Nandavaram of Banaganapallemandal in
Kurnool district of Andhra Pradesh for the study. Initial data on age, stage of lactation, parity, pregnancy status, the animal's daily feed intake, daily milk yield and fat content in milk were recorded.

\begin{tabular}{|l|l|}
\hline Breed & $\begin{array}{l}\text { Number of } \\
\text { animals (n) }\end{array}$ \\
\hline Crossbred Jersey cows & 9 \\
\hline $\begin{array}{l}\text { Crossbred Holstein } \\
\text { Friesian cows }\end{array}$ & 10 \\
\hline Ongole cows & 11 \\
\hline
\end{tabular}

\section{Animal body weight}

The animal's body weight was recorded based on length and heart girth measurements using Shaeffer`s formula (Khan et al., 2003).

BW $(\mathrm{kg})=([($ heart girth $(\mathrm{cm}) / 2.54) 2 \mathrm{x}$ length of the body $(\mathrm{cm}) / 2.54] / 300) \times 0.4536$.

\section{Formulation of balanced ration}

The nutrient requirements and quantity of each ingredient for balanced ration was calculated based on milk yield, milk fat percent, body weight, stage of lactation and pregnancy statusbefore treatment was used to prepare balanced ration with android application "Ration Formulator" developed by Sri Venkateswara Veterinary University, Tirupati.

\section{Statistical analysis}

Statistical analysis of the data was done by Students ' $t$ ' test as per Snedecor and Cochran (1986) with the SPSS package (1999).

\section{Results and Discussion}

\section{Body weight}

The data on length (L), heart girth (G) and body weights (W) of the Jersey crossbred (JX), Holstein Friesian crossbred (HFX) and 
Ongole cows were presented in table 1 . The data revealed that the mean $\mathrm{L}, \mathrm{G}$, body weight gain of JX cows in $T_{1}$ and $\mathrm{T}_{2}$ were $165.66 \pm 4.11 \mathrm{~cm}, \quad 130.95 \pm 2.88 \mathrm{~cm}$ and $170.74 \pm 3.78 \mathrm{~cm}, 137.72 \pm 2.7 \mathrm{~cm}$ respectively. The mean body weight in $\mathrm{T}_{1}$ and $\mathrm{T}_{2}$ were recorded as $265.79 \pm 18.12 \mathrm{~kg}$ and $302.03 \pm 17.38 \mathrm{~kg}$ respectively. From the data it was found that $13.9 \%$ more body weight in JX cows through supplementation of balanced ration.

Mean L, Gof HFX cows in $\mathrm{T}_{1}$ and $\mathrm{T}_{2}$ were $168.15 \pm 3.55 \mathrm{~cm}, \quad 142.99 \pm 2.68 \mathrm{~cm}, \quad$ and $170.05 \pm 3.94 \mathrm{~cm}, 148.97 \pm 2.15 \mathrm{~cm}$ respectively. From the data it was found that $9.32 \%$ more body weight was recorded in $\mathrm{T}_{2}$
$(320.26 \pm 17.09 \mathrm{~kg})$ over $\mathrm{T}_{1}(350.65 \pm 16.16 \mathrm{~kg})$. Similarly the mean L, G of Ongole cows in $\mathrm{T}_{1}$ and $\mathrm{T}_{2}$ were $155.23 \pm 3.83 \mathrm{~cm}, 127.91 \pm 4.41$ and $155.05 \pm 3.12 \mathrm{~cm}, \quad 136.93 \pm 4.11 \mathrm{cmrespectively.}$ The mean body weight in $T_{1}$ and $T_{2}$ were recorded as $233.55 \pm 19.8 \mathrm{~kg}$ and $271.68 \pm 18.53 \mathrm{~kg}$ respectively. From the data it was found that $16.3 \%$ more body weight was recorded in $\mathrm{T}_{2}$ over $\mathrm{T}_{1}$.

The experiment revealed that among the three breeds more body weight gain in 30 days was recorded in Ongole breed $(38.2 \mathrm{~kg})$ followed by JX (36.8kg) and HFX (29.11kg). Garg et al., (2013) observed that through adopting ration balancing techniques $7.56 \mathrm{~kg}$ body weight can be improved.

Table.1 Showing body measurements and body weights of different breeds

\begin{tabular}{|l|l|c|c|c|}
\hline Treatments & Particulars & $\begin{array}{c}\text { Jersey crossbred } \\
\text { cows } \\
\text { N=9 }\end{array}$ & $\begin{array}{c}\text { HF crossbred cows } \\
\text { N=10 }\end{array}$ & $\begin{array}{c}\text { Ongole } \\
\text { N=11 }\end{array}$ \\
\hline \multirow{2}{*}{ T1 } & L $(\mathrm{cm})$ & $165.66 \pm 4.11$ & $168.15 \pm 3.55$ & $155.23 \pm 3.83$ \\
\cline { 2 - 5 } & G $(\mathrm{cm})$ & $130.95 \pm 2.88$ & $142.99 \pm 2.68$ & $127.91 \pm 4.41$ \\
\cline { 2 - 5 } & Body weight $(\mathrm{kg})$ & $265.79 \pm 18.12$ & $320.26 \pm 17.09$ & $233.55 \pm 19.8$ \\
\hline & L $(\mathrm{cm})$ & $170.74 \pm 3.78$ & $170.05 \pm 3.94$ & $155.05 \pm 3.12$ \\
\cline { 2 - 5 } & G $(\mathrm{cm})$ & $137.72 \pm 2.7$ & $148.97 \pm 2.15$ & $136.93 \pm 4.11$ \\
\cline { 2 - 5 } & Body weight $(\mathrm{kg})$ & $302 . .03 \pm 17.38$ & $350.65 \pm 16.16$ & $271.68 \pm 18.52$ \\
\hline
\end{tabular}

Table.2 Showing production performance of different breeds

\begin{tabular}{|c|c|c|c|c|c|c|c|}
\hline \multirow{2}{*}{ S. No } & \multirow{2}{*}{ Breed } & \multicolumn{3}{|c|}{3.5 FCM yield (kg/day) } & \multicolumn{3}{c|}{ Milk fat (grams/kg) } \\
\cline { 3 - 9 } & & $\mathbf{T}_{\mathbf{1}}$ & $\mathbf{T}_{\mathbf{2}}$ & $\mathbf{\%}$ increase & $\mathbf{T}_{\mathbf{1}}$ & $\mathbf{T}_{\mathbf{2}}$ & $\mathbf{\%}$ increase \\
\hline $\mathbf{1}$ & JX & $8.49 \pm 0.74$ & $11.64 \pm 1.09$ & 33.52 & $33.3 \pm 2.71$ & $41.5 \pm 2.82$ & 24.62 \\
\hline $\mathbf{2}$ & HFX & $10.63 \pm 1.1$ & $12.14 \pm 1.12$ & 14.25 & $37.4 \pm 3.42$ & $39.6 \pm 3.1$ & 5.88 \\
\hline $\mathbf{3}$ & Ongole & $2.399 \pm 0.19$ & $3.57 \pm 0.35$ & 48.7 & $47.6 \pm 2.19$ & $59.9 \pm 2.66$ & 25.84 \\
\hline
\end{tabular}

\section{Production performance}

The 3.5\% FCM yield and fat content in the milk (grams) particulars are presented in table 2. The data revealed that among the three breeds highest response of $48.7 \%$ increase in $3.5 \%$ FCM yield was recorded in Ongole followed by Jersey crossbred (33.5\%) and $\mathrm{HF}$ crossbred $(14.25 \%)$ cows. The increase in milk fat was highest in Ongole cows $(25.84 \%)$ followed by Jersey crossbred cows $(24.6 \%)$ and HF crossbred cows (5.88\%). From this study it was observed that the Ongole cows are having greater genetic potential for milk 
production and that can be achieved through balanced feeding. Garg et al., (2013) observed that improvement of daily milk yield from 0.2 to $1.2 \mathrm{~kg}$ and fat level in milk from 1.0 to 9.0 $\mathrm{g} /$ kgin cows by adopting Ration Balancing techniques. Sherasia et al., (2016) reported that balanced feeding improved fat corrected milk by 0.6 and $0.7 \mathrm{~kg} / \mathrm{animal} / \mathrm{day}$, whereas, feeding cost reduced by 14 and $18 \%$ in cows and buffaloes, respectively.

The improvement in milk yield and milk fat level in cows and buffaloes after feeding a nutritionally balanced ration could be due to increased rumen microbial $\mathrm{CP}$ synthesis due to more optimal rumen function because of the more balanced nutrient supply.The results of the present study are in conformitywith Haldar and Rai (2003) who also reported an improvement in milk yield due to supplementation of an energy/ mineral mixture in lactating ruminants.

In conclusions, balanced feeding improves the body weight in three breeds of cattle. Improvement in milk production was observed in the animals fed with balanced ration compared to farmers' practice of conventional feeding. The indigenous cattle had more response towards balanced feeding compare to other breeds with regard to body weight gain and milk improvement. The android application developed by Sri Venkateswara Veterinary University, Tirupati was found efficient tool for calculation of nutrient requirements and preparation of balanced ration utilizing locally available feed and fodder resources for different type of animals in various stages.

\section{References}

Garg M R, Sherasia P L, Phondba B T, Shelke S K and Patel C T (2013) Effect of feeding balanced ration on milk production, enteric methane emission and metabolic profile in crossbred cows under field conditions. Indian J. Dairy Science, 66(2):113-119 (2013).

Haldar, S. and Rai, S.N. 2003. Effects of energy and mineral supplementation on nutrient digestibility and efficiency of milk production in lactating goats. Indian J. Anim. Nutr., 20: 244251.

Sherasia P.L

Garg M.R., Phondba B.T., Hossain S.A. , Patel B.P. (2016) Milk Production, Methane Emission, Metabolic Profile and Drinking Water Use Efficiency of Lactating Animals Fed Balanced Rations. Animal Nutrition and Feed Technology 16(2): 239-250.

\section{How to cite this article:}

Krishna Murthy Atturi, Ajay Singh, Kalyana Chakravarthi Matha, Dhanalakshmi Guduru and Prasad, Y.G. 2018. Effect of Balanced Ration Supplementation on Body Weight Gain and Milk Yield in Different Breeds of Cattle. Int.J.Curr.Microbiol.App.Sci. 7(11): 2443-2446. doi: https://doi.org/10.20546/ijcmas.2018.711.278 